\title{
Economic aspects of caesarean section and alternative
}

\section{modes of delivery}

\section{Authors:}

Stavros Petrou $\mathrm{PhD}^{1}$; Jane Henderson $\mathrm{MSc}^{2}$; Cathryn Glazener $\mathrm{PhD}^{3}$

1: Health Economist, National Perinatal Epidemiology Unit, Institute of Health Sciences, University of Oxford, Old Road, Headington, Oxford OX3 7LF, UK.

Telephone: 00441865226829

FAX: $\quad 00441865227002$

E-mail: stavros.petrou@perinatal-epidemiology.oxford.ac.uk

2: Health Economics Researcher, National Perinatal Epidemiology Unit, Institute of Health Sciences, University of Oxford, Old Road, Headington, Oxford OX3 7LF, UK.

Telephone: 00441865226855

FAX: $\quad 00441865227002$

E-mail: jane.henderson@perinatal-epidemiology.oxford.ac.uk

3: Senior Clinical Research Fellow, Health Services Research Unit, University of Aberdeen, Polwarth Building, Foresterhill, Aberdeen AB9 2ZD, UK.

Telephone: 00441224553732

FAX: $\quad 00441224403018$

E-mail: c.glazener@abdn.ac.uk

Contact for correspondence and reprints: Dr. Stavros Petrou 


\begin{abstract}
Increases in caesarean section rates worldwide have raised questions about the economic implications of caesarean section and alternative modes of delivery. In this chapter, economic aspects of caesarean section and alternative modes of delivery are reviewed and areas where further research is required are identified. The chapter presents the results of a systematic review of the literature and analyses of three large observational data sets. It provides evidence for the cost of labour and delivery, the cost of the postnatal stay and the cost of the long-term health consequences of alternative modes of delivery. The chapter highlights the paucity of methodologically robust economic analyses in this area of health care and concludes that primary research is required to estimate the cost and utilisation of services attributable to caesarean section and alternative modes of delivery. Future research studies should recognise the long-term health service costs and the costs that arise outside the health service, which are likely to vary according to mode of delivery.
\end{abstract}

Key words: cost, economic evaluation, resource, caesarean section, mode of delivery

Word count: 7819 (excluding summary) 


\section{Introduction}

Caesarean section is the most common major hospital surgical procedure in the industrialised world, accounting for 17 percent of all deliveries in England in 1997-98 [1], 18 percent in Wales in 1997-98 [1] and 19 percent in Scotland in 1998 [2]. Similar caesarean section rates have been reported in other industrialised nations [3]. Moreover, a number of clinical, provider and sociodemographic factors appear to be generating steady increases in caesarean rates worldwide [4-6]. Consequently, questions have emerged about the economic implications of caesarean section and alternative modes of delivery.

It is generally considered to be axiomatic that caesarean sections are more expensive than spontaneous vaginal deliveries. The additional costs of a caesarean section are attributed to the additional staff inputs during the delivery itself and an extended inpatient stay. However, much of the evidence that is presented in the medical literature is of poor methodological quality and does not exhibit a clear understanding of economic issues. In this chapter, we present the results of a review of economic aspects of caesarean section and alternative modes of delivery. In the process, we identify a number of areas whether further research is required.

\section{Definitions and terminology}

Throughout this chapter we refer to terms that are often disputed in meaning. The term cost is commonly used to refer to the value of resources incurred by a form of care. This involves considering the benefits or social sacrifices foregone by investing in a particular form of care, referred to by economists as opportunity costs. The costs of care can be divided into direct 
costs, indirect costs and intangible costs. Direct costs represent the resources purchased directly as a result of the health care activity. This category may be subdivided into fixed costs which do not vary as output varies, for example, depreciation costs and rent, and variable costs which are directly related to output and include wages and the running costs of equipment. Indirect costs represent the element of indirect consumption of resources in the production process, for example the value of lost earnings by patients or carers of patients who are unable to work as a result of the health care activity. A further category of costs are the intangible or psychosocial costs, defined by Drummond et al. [7] as "costs borne externally to the health sector, patients and their families.” This refers to the element of pain or grief experienced by patients and their families and friends. Economists often shy away from valuing such costs and, as a result, appear to set them equal to zero across disease groups. Sometimes these costs are estimated as part of outcome evaluations, where subjects are asked questions about coping, reassurance, emotion, pain, grief or other intangibles and may be reflected in generic health status measures such as the SF-36 [8] or the EQ-5D [9].

Economic studies that compare the costs and outcomes of two or more alternative forms of care are referred to as economic evaluations. Although the different forms of economic evaluation consider the same categories of costs, they differ in the manner in which outcomes are measured and valued. Cost benefit analysis measures the costs and outcomes of health care activities in the same monetary units and attempts to ascertain whether the activities can be justified per se, that is, whether the benefits of the activities exceed their costs. Cost effectiveness analysis also compares the costs of health care activities to their outcomes, but the outcomes are measured in natural or physical units, such as life years gained or hospital days saved. Finally, cost utility analysis is a refinement of cost effectiveness analysis in that it constructs a single index of outcomes that reflects preferences for each possible outcome. 
Potential instruments for measuring health outcomes within a cost utility framework include the quality-adjusted life year (QALY) [10], the healthy years equivalent (HYE) [11] and the saved young life equivalent (SAVE) [12].

\section{Methodological considerations}

Estimates of the economic implications of caesarean section and alternative modes of delivery require a number of methodological considerations. Firstly, the process of cost measurement can encompass a variety of methods of varying degrees of complexity. The most common alternative approaches are based on cost accounting methods, either using detailed information about resources used by individual patients (the "bottom up" approach), or by allocation of total costs by unit workload (the “top down” approach). Many studies, particularly those conducted in countries, such as the United States, where there is a comprehensive system of billing and fee-for-service payment of providers, cite charges for caesarean section and alternative modes of delivery rather than costs. However, it is worth noting that health care charges may include elements arising from corporate financial decisions [13] and may therefore be poor proxies for the costs of providing intrapartum care.

Secondly, specific organisational features will affect the costs of caesarean section and alternative modes of delivery. In theory, large obstetric centres should be able to provide intrapartum care more cheaply than smaller centres because of economies of scale. Despite this theory, some empirical evidence suggests that large obstetric centres produce more expensive deliveries because of the additional high technology interventions that women receive [14]. Costs may be affected by local factors such as the level, duration and efficiency of care provided by medical and nursing staff, as well as by variations in the unit costs of 
individual resource inputs [15]. Variations in costs may simply be the result of variations in practice patterns between centres that have developed for historical, cultural or legal reasons. For example, some tertiary obstetric centres provide one to one nursing attention during the passive period of the second stage of labour, whilst many nontertiary obstetric centres provide intermittent nursing support during this period. A further consideration is that the costs of caesarean section and alternative modes of delivery may be affected by the capacity at which the system is operating. For example, the average cost per delivery is considerably less if the delivery suite is operating at peak capacity rather than at $50 \%$ capacity.

Thirdly, caesarean section and alternative modes of delivery are likely to have resource consequences for sectors of the economy other than the health service, as well as for individuals. For example, women giving birth may require support from statutory, voluntary and informal care services upon their discharge from hospital. Their partners, families and friends may have to forego other productive activities (paid or unpaid work) in order to spend time with them and the newborn; their transport costs to and from the hospital may be considerable, and care for other children may have to be arranged. As a consequence, economic studies of caesarean section and alternative modes of delivery should ideally be conducted from as broad a perspective as possible, particularly if the form of care being evaluated may result in cost shifting to other sectors of the economy.

Fourthly, the costs of caesarean section and alternative modes of delivery are likely to continue over the longer term and should therefore be recognised by economic analyses. Women being delivered by caesarean section, for example, may have additional health care needs which lead to hospital readmissions or increased contacts with general practitioners and other health care providers, as well as additional care requirements for everyday living [16]. 
Moreover, production losses may ensue as a result of the woman's sustained absence from the labour market, particularly if the economy as a whole is operating at close to full employment [17]. Table 1 lists the potential resource requirements that should be considered by economic studies of caesarean section and alternative modes of delivery.

Fifthly, the cost of caesarean section and alternative modes of delivery is likely to vary over time as a result of technical improvements. Therefore, any predictions of costs should account for future efficiencies that result from learning or from technological development. According to Luce and Elixhauser [18], this process entails estimating improvements in the productivity of medical and nursing staff, as well as taking into account hardware and software changes, changes in the costs of individual resource inputs, changes in the scale of the care approach being considered, and any other developments in the technology.

\section{Methods}

Several strategies were used to identify relevant economic studies of caesarean section and alternative modes of delivery. A number of computerised databases were searched:

MEDLINE, CINAHL, EconLit, Science Citation Index (SCI), Social Science Citation Index, Index to Scientific and Technical Proceedings (ISTP), British Library Inside Information (BLII), EMBASE, Cochrane Library (CDSR), York Database of Abstracts of Reviews of Effectiveness (DARE), NHS Economic Evaluation Database (NEED) and the Database of Consortium of University Research Libraries (COPAC). Additionally, formal searches of the ASLIB Index to British Theses and Current Research in Britain (CRIB) were conducted for masters and $\mathrm{PhD}$ theses accepted by British universities addressing economic aspects of caesarean section and alternative modes of delivery. Books and pamphlets held in the 
National Perinatal Epidemiology Unit library with material relating to economic aspects of caesarean section and alternative modes of delivery were hand searched. Published and unpublished manuscripts identified through fellow health economic researchers and by other means were reviewed to determine their relevance to the study. Finally, bibliographies of economic evaluations [19-20] were scanned for studies that might have been missed using other sources.

The search terms applied to all electronic databases were identified following extensive pilot searches on MEDLINE. Studies were excluded from the literature searches if they were published before 1990, if they had been conducted in developing countries, if the abstract had not been published in the English language or if the focus was animal research. The majority of foreign language manuscripts identified by the literature searches were not translated into the English language and we may therefore have overlooked important foreign language studies.

A total of 975 studies were identified by these literature searches. Each of these studies was categorised on the basis of its title and abstract; 142 studies were considered to contain relevant economic information and were obtained from local and British libraries. Upon full examination, it was concluded that 49 studies examined economic aspects of caesarean section and alternative modes of delivery, and contained useful primary or secondary cost or utilisation data. The results of these 49 studies are discussed in detail in this chapter. All cost data cited in this chapter were converted from their respective currencies into UK $£$ Sterling using Purchasing Power Parities supplied by the Organisation for Economic Co-operation and Development. Once converted to UK $£$ Sterling, the cost data were inflated to 1998 prices using the NHS Hospital and Community Health Services Pay and Prices Inflation 
Index. The results of the studies are, in the main, presented and discussed in a qualitative manner. Pooling of economic data was only performed for studies that were similar in design and that were sufficiently transparent and robust in their methodology.

In addition to conducting literature searches, we also accessed and analysed three large observational data sets. Firstly, data from hospitals in the former North West Thames Region in England that contribute to the St. Mary’s Maternity Information System (SMMIS) formed a source for hospital utilisation data for the years 1995-97. We report trends in length of labour and duration of postnatal stay as medians as well as means because of the skewed nature of these distributions. Secondly, staff and material inputs required by caesarean section and alternative modes of delivery were drawn from a survey of 21 maternity units throughout the European Union [21]. Senior caregivers at each of the maternity units were asked to identify the numbers of staff in different categories who were normally present for different modes of delivery, and the length of time taken for each procedure. Quantities of resource items used, including drugs, dressings and sterile packs, were calculated for each mode of delivery. These data were obtained either from routine hospital statistics or from direct observation or knowledge of events on the part of the senior caregivers. Thirdly, estimates of the utilisation of health and informal care services following women's initial discharge from hospital were drawn from a random sample of 20 percent of all women receiving postnatal care in the Grampian Region of Scotland during the years 1990-91 [22]. A total a of 1242 women were surveyed and asked to return self-completed questionnaires at one week, eight weeks and 12 to 18 months postpartum. 


\section{Results}

\section{$\underline{\text { Cost of labour and delivery }}$}

The cost of labour and delivery is dependent upon the duration of labour and the staff and material inputs entailed by alternative modes of delivery. Reliable hospital data for 111,321 deliveries recorded by the St. Mary’s Maternity Information System (SMMIS) during the years 1995-97 showed that the duration of labour for women undergoing instrumental vaginal delivery or emergency caesarean section was longer than the duration of labour experienced by women delivered spontaneously (Table 2). The mean (median) duration of labour for women undergoing a spontaneous vaginal delivery was 6.35 hours (5.41 hours). This compared to a mean (median) duration of labour of 11.19 hours (11.07 hours) for delivery by forceps, 10.59 hours (10.42 hours) for delivery by ventouse and 7.30 hours (6.42 hours) for delivery by emergency caesarean section. The duration of labour appears to be declining over time for all modes of delivery, but a consistent pattern of prolonged labour for instrumental vaginal deliveries and emergency caesarean sections remains. This is unsurprising given that many instrumental vaginal deliveries and emergency caesarean sections result from diagnoses of dystocia [23]. A prolonged duration of labour is likely to increase delivery suite or operating theatre overheads, although this is dependent upon the opportunity costs that can be attributed to use of the delivery room or operating theatre. Depending on the delivery capacity of the obstetric centre, there may be circumstances in which there is no pressure on delivery suite or operating theatre usage and, consequently, revenue overheads may be incurred by keeping the suite or theatre operational in the event of complications [24]. 
The staff costs incurred during labour and delivery are dependent upon the level and mix of staff performing and assisting the delivery, the duration of their support and the unit costs of staff inputs. These factors, in turn, will depend upon local practices, as well as upon the way in which wider health services are organised [25-26]. The survey of European Union maternity units described earlier was designed to evaluate intrapartum care in obstetric centres of varying size within a wide range of health care systems [21]. Table 3 presents the mean number of medical and nursing staff normally present during caesarean section and alternative modes of delivery at these maternity units. It can be seen that larger numbers of midwifery and nursing staff, additional junior staff and senior medical staff normally attend an instrumental vaginal delivery than a spontaneous vaginal delivery. Similarly, larger numbers of all categories of staff normally attend a caesarean section than an instrumental vaginal delivery. These data, however, do not tell us whether staff support is continuous during the entire period of labour and delivery, or whether it is intermittent in nature. For the purposes of a rigorous economic analysis of caesarean section and alternative modes of delivery, observational research is required to estimate staff inputs and requirements during labour and delivery. There are several methods of undertaking this, including the use of tick charts, diaries recording allocation of staff time, and direct observation by an independent observer which would require the use of a stopwatch and a data recording sheet. For the purposes of economic analysis, an assessment is also required of the opportunity cost of staff resources, that is, whether all staff time has an alternative use and can be redeployed to assist with alternative activities at short notice. There may be circumstances in which the additional staff inputs entailed by a caesarean section or an instrumental vaginal delivery are not easily transferable to alternative activities and will therefore have a negligible opportunity cost. 
Eleven published studies provide monetary estimates of the staff inputs associated with labour and delivery. Seven of these studies were from the United States (US) and report staff 'fees’ of between $£ 581$ [27] and £1358 [28] for a spontaneous vaginal delivery and staff fees of between $£ 1011$ [27] and $£ 1927$ [29] for a caesarean section. Staff fees for instrumental vaginal deliveries have not been reported in the US literature. Three UK studies report the hourly rates of pay for different categories of staff required by alternative modes of delivery [30-32], whilst an Italian study reports total staff costs attributable to a spontaneous vaginal delivery and a caesarean section [33].

Alternative modes of delivery also make different demands on hospital equipment and medical and surgical supplies (Table 1). Instrumental deliveries require the use of forceps and vacuum extractors, whilst caesarean sections are carried out under regional (epidural or spinal block) or general anaesthesia, and require the use of a wide range of needles, syringes, tubes, attachments and swabbing solutions. Disposable medical and surgical supplies incur an opportunity cost usually considered by economists to be equivalent to their market price, whilst capital outlays on equipment are usually annuitised over their useful lifetimes in order to account for depreciation costs [7]. Very few studies have adequately estimated the cost of the equipment and medical and surgical supplies attributable to caesarean section and alternative modes of delivery. One UK study estimated the cost of a range of consumables such as surgical trays and gowns [31], whilst five other studies report the costs of different consumables, such as those associated with epidural or spinal analgesia [30,34], and analgesia following vaginal and caesarean birth [33,35-36]. 


\section{Cost of postnatal stay}

The cost of care provided to the mother and infant on the postnatal ward constitutes a significant proportion of the total cost of caesarean section and alternative modes of delivery. Table 4 shows the duration of postnatal stay by mode of delivery for the 111,321 deliveries recorded by the St. Mary’s Maternity Information System (SMMIS) during the years 199597. In the former North West Thames Region of England, 17.6\% of all deliveries were by caesarean section, and a further $12.3 \%$ were by instrumental vaginal delivery. The data show that the duration of postnatal stay was longer after instrumental vaginal delivery than after spontaneous vaginal delivery, and longer after caesarean section than after instrumental vaginal delivery. The mean (median) duration of postnatal stay for spontaneous vaginal delivery, forceps delivery, ventouse delivery, elective caesarean section and emergency caesarean section was 1.58 (1), 2.71 (2), 2.44 (2), 4.52 (4) and 5.05 (5) days, respectively. Moreover, this differential in the duration of postnatal stay is maintained when the data is analysed by gestational age, multiparity, parity and year of birth. Not surprisingly, the differential in the duration of postnatal stay is reflected in published cost estimates. Clark et al. [37] report a two-fold differential in the cost of postnatal care between a spontaneous vaginal delivery and an instrumental delivery. The differential in the cost of postnatal care was almost four-fold when a spontaneous vaginal delivery was compared to an emergency caesarean section. For all modes of delivery, the cost of postnatal care constituted approximately three-quarters of the total cost. A note of caution should be added at this point. A common misconception held by analysts is that the mean cost per day (per diem) of the postnatal stay remains constant throughout its duration. However, an Australian study has shown that the per diem declines with each day of the postnatal stay from $£ 60$ - $£ 111$ on day 1 to $£ 50$-£92 on day 4 or more [38]. Economic analyses of hospital discharge policies should, 
therefore, guard against overestimating the potential savings that might accrue from an early discharge policy, whatever the mode of delivery.

\section{$\underline{\text { Summary costs of initial hospital stay }}$}

A number of published studies cite total costs or charges for a caesarean section or an alternative mode of delivery. A total of 20 studies cite total US charges for a caesarean section, but generally do not differentiate between the different forms of caesarean section (e.g. elective or emergency, antepartum or intrapartum) or disaggregate the resource components of the charge. Reported total US charges for a caesarean section ranged between $£ 958$ [39] and £11,601 [40]. One study from Canada, 5 from the United Kingdom, 1 from Australia, 1 from Italy and 2 from Sweden cite total caesarean section costs or charges. These were found to range between $£ 66$ in the United Kingdom [32] and £2024 in Australia [41]. Three of these studies report total costs or charges for an emergency caesarean section [37,42-43]. A further five studies report total costs or charges for an elective caesarean section $[37,42-45]$.

As with the caesarean section literature, published studies that cite total costs or charges for a spontaneous vaginal delivery or an instrumental vaginal delivery generally failed to disaggregate the resource components of the cost or charge. Total costs or charges for a spontaneous vaginal delivery ranged between $£ 470$ [39] and $£ 8420$ [42] in the US literature and between $£ 36$ [33] and $£ 1427$ [41] in the non-US literature. Only seven studies cite total costs for an instrumental vaginal delivery, none of which were from the United States. These costs ranged between $£ 233$ in the United Kingdom [46] and £1897 in Australia [41]. 
The range of cost estimates for alternative modes of delivery reported by studies that were considered by the authors to be transparent and robust in their costing methodology is shown in Table 5. The data suggest that a caesarean section is more costly than an instrumental vaginal delivery and that an instrumental vaginal delivery is more costly than a spontaneous vaginal delivery. Because of differences in the resource components of each of the individual cost estimates, we feel that it would be misleading to provide summary statistics. However, comparisons are made with National Health Service (NHS) Reference Costs which are costs routinely collected by England's Department of Health from all NHS trusts except specialist community, mental health and ambulance trusts and consequently stratified by Health Resource Group. Table 5 shows a reassuring correlation between cost estimates cited in the published literature and costs routinely used to inform Department of Health policy making.

\section{Costs following initial hospital stay}

Alternative modes of delivery are considered to have differential long-term effects on a woman’s health. Midpelvic procedures increase the risk of neonatal morbidity, including asphyxia, fractures and palsies [47], whilst caesarean sections may contribute to higher rates of postpartum depression, post-traumatic stress reactions, placenta praevia, abruptio placenta, subsequent miscarriage and decreased fertility rates [48-50]. An assessment of the economic implications of the long term health consequences of caesarean section and alternative modes of delivery would inform the planning of services and would provide a basis for assessing competing strategies for research and prevention.

There is a paucity of published studies that address the economic implications of the longterm health consequences of caesarean section and alternative modes of delivery. A recent 
retrospective cohort study from the Washington State Birth Events Record Database in the United States found that women undergoing a caesarean section during the years 1987-96 were $80 \%$ more likely to be rehospitalised during the first 60 days postpartum than women undergoing a spontaneous vaginal delivery [16]. Furthermore, women undergoing an instrumental vaginal delivery were found to be $30 \%$ more likely to be rehospitalised during the first 60 days postpartum than women undergoing a spontaneous vaginal delivery. The main causes for rehospitalisation following a caesarean section were uterine infection, obstetrical surgical wound complications, and thromboembolic conditions. Among women undergoing an instrumental vaginal delivery, the main causes for rehospitalisation were postpartum haemorrhage, obstetrical surgical wound complications and pelvic injury. The study of the utilisation of post-discharge health and informal care services in the Grampian Region of Scotland [22] found that women undergoing an instrumental vaginal delivery or a caesarean section consumed a greater number of health and informal care services during the first two months postpartum (Table 6). The number of contacts with general practitioners and informal carers, and readmissions to hospital were significantly greater among women undergoing an instrumental vaginal delivery or a caesarean section, whilst the number of contacts with health visitors tended towards significance.

\section{Conclusions}

This chapter has presented the results of a review of economic aspects of caesarean section and alternative modes of delivery. It has highlighted the lack of methodologically robust economic research applied to caesarean section and alternative modes of delivery. Many of the economic studies reviewed were conducted in the United States where charges are often used as proxies for costs and where the unique organisation of health care services makes it 
inappropriate to generalise economic results to United Kingdom and other settings. The majority of the reviewed studies were conducted from a health service perspective and, therefore, excluded costs borne by the patient and her family as well as wider costs to society. The majority of studies also limited their analysis to costs incurred during the initial hospital stay and therefore failed to take account of the economic implications of the long term health consequences of caesarean section and alternative modes of delivery.

In the light of the shortcomings in much of the existing literature, we recommend that rigorous economic analyses be conducted to identify the resources required and the unit costs associated with caesarean section and alternative modes of delivery. Economic analyses of caesarean section should be subdivided by whether the delivery was planned before the labour (elective) or not (emergency), and by whether it was performed before the onset of labour (antepartum) or during labour (intrapartum). These economic analyses should ideally adopt a broad perspective and include:

- costs attributable to the labour and delivery;

- costs attributable to the postnatal stay:

- $\quad$ costs of hospital readmissions;

- costs of short-term maternal and neonatal adverse outcomes, which could be borne by the health sector or other sectors of the economy;

- costs of long-term maternal and neonatal adverse outcomes, which could be borne by the health sector or other sectors of the economy;

- $\quad$ direct costs of the health care process borne by women and their carers;

- $\quad$ costs associated with lost productivity (indirect costs);

- $\quad$ costs associated with pain, fear and suffering (intangible costs). 
A number of methods can be used to estimate the resources required by caesarean section and alternative modes of delivery. Resource quantities can be estimated within randomised clinical trials or by comparison of data from routine health service information sources, from primary surveys, from reviews of published studies, or from expert opinion (Delphi panels). It is worth noting that it is unlikely that a complete profile of resource use can be obtained from a single source. Therefore, less well controlled sources of resource use data are always needed and used in some form, especially in the extrapolation from intermediate to long term outcomes.

The unit costs attributable to the resource implications of caesarean section and alternative modes of delivery can be derived using a number of methods. The data may come from nationally available published studies, salary review boards for health service personnel, locally held data sources or ad hoc studies reported in the literature. Additionally, the unit cost data may be generated from first principles at the study sites themselves using small accounting studies. These accounting studies may themselves use a number of methods including time and motion studies, diary methods, work sampling, interviews with key caregivers, case note analysis and patient activity databases.

No economic evaluations of caesarean section and alternative modes of delivery have been reported in the literature. This is perhaps unsurprising given that the decision about mode of delivery has, until recently, been considered to be a solely clinical one. That no economic evaluations have been conducted comparing similar methods of delivery, such as vaginal birth facilitated by forceps compared to ventouse, is perhaps more surprising given that randomised controlled trials have been conducted comparing these procedures [51]. It would appear possible to conduct economic evaluations of alternative forms of instrumental vaginal 
delivery. The element of maternal choice, although currently only making a small impact, may grow in importance as a factor in increasing caesarean section rates. It is also appropriate that the economic implications of this factor are considered, as has been suggested elsewhere [52].

In conclusion, the following table provides a summary of priorities for future research:

- $\quad$ Primary costing study of caesarean section using rigorous bottom-up costing methodology;

- $\quad$ Primary costing study of alternative modes of delivery using rigorous bottom-up costing methodology;

- Relative assessment of the contribution of the labour and delivery, the postnatal stay and short-term and long-term maternal and neonatal adverse outcomes to the total cost of caesarean sections and alternative modes of delivery;

- Relative assessment of the contribution of health service costs, costs to other sectors of the economy and costs to the patient and her carers to the total cost of caesarean sections and alternative modes of delivery;

- Economic evaluation of alternative forms of instrumental vaginal delivery. 


\section{Summary}

This chapter presents the results of a review of economic aspects of caesarean section and alternative modes of delivery. It highlights the lack of methodologically robust economic analyses of caesarean section and alternative modes of delivery. Many of the economic studies identified by a systematic review of the literature were conducted in the United States where charges are often used as proxies for costs and where the unique organisation of health care services makes it inappropriate to generalise economic results to United Kingdom and other settings. The majority of the reviewed studies were conducted from a health service perspective and, therefore, excluded costs borne by the patient and her family as well as wider costs to society. The majority of studies also limited their analysis to costs incurred during the initial hospital stay and therefore failed to take account of the economic implications of the long term health consequences of caesarean section and alternative modes of delivery.

The chapter highlights areas where further research is required. In particular, primary costing studies of caesarean section and alternative modes of delivery are required to inform the planning of services and to provide a basis for assessing competing strategies for research and prevention. These studies should identify the key resource consequences of caesarean section and alternative modes of delivery during the initial hospital stay and over the longer-term and apply units costs, which have been calculated using sound accounting methods, to each item of resource use. Furthermore, economic evaluations of alternative modes of delivery should be considered where appropriate. 


\section{Acknowledgements}

We gratefully acknowledge the help of Richard Harris of St. Mary’s Hospital for providing data on SMMIS. Stavros Petrou and Jane Henderson are funded by the Department of Health, whilst Cathryn Glazener receives support from the Wellcome Trust. 


\section{References}

(1) English National Board. Midwifery practice: identifying the developments and the differences. London: English National Board, 1999.

(2) Information and Statistics Division Scotland. Scottish health statistics 1998. No.40, London: The Stationery Office, 1999.

(3) Stirrat G. The place of caesareans section. Contemporary Reviews in Obstetrics and Gynaecology 1998;10: 177-83.

(4) Fraser W, Maunsell E, Hodnett E \& Moutquin JMM. Randomized controlled trial of a prenatal vaginal birth after cesarean section education and support program. American Journal of Obstetrics and Gynecology 1997;176(2): 419-25.

(5) Paterson-Brown S. Should doctors perform an elective caesarean section on request? Yes, as long as the woman is fully informed. British Medical Journal 1998;317(7156): 462-3.

(6) Howard RJ. Elective caesarean section request. Pregnant women should have choices. [letter]. British Medical Journal 1999;318(7176): 122.

(7)* Drummond MF, Stoddart GL \& Torrance GW. Methods for the economic evaluation of health care programmes. Oxford: Oxford University Press, 1987. 
(8) Brazier J. The SF-36 health survey questionnaire - a tool for economists. Health Economics 1993;2: 213-5.

(9) EuroQol Group. EuroQol - a new facility for the measurement of health-related quality of life. Health Policy 1990;16: 199-208.

(10) Torrance GW \& Feeny D. Utilities and quality-adjusted life years. International Journal of Technology Assessment in Health Care 1989;5: 559-75.

(11) Mehrez A \& Gafni A. Quality-adjusted life years, utility theory, and healthy-years equivalents. Medical Decision Making 1989;9: 142-9.

(12) Nord E. An alternative to QALYs: the saved young life equivalent (SAVE). British Medical Journal 1992;305: 875-7.

(13)* Finkler SA. The distinction between costs and charges. Annals of Internal Medicine 1982;96: 102-9.

(14) Hein HA \& Ferguson NN. The cost of maternity care in rural hospitals. Journal of American Medical Association 1978;240: 2051-2.

(15)* Finkler MD \& Wirtschafter DD. One health maintenance organization's experience: obstetric costs depend more on staffing patterns than on mode of delivery. Journal of Perinatology 1997; 17(2): 148-55. 
(16)* Lydon-Rochelle M, Holt VL, Martin DP \& Easterling TR. Association between mode of delivery and maternal rehospitalization. Journal of American Medical Association 2000;238(18): 2411-2416.

(17) Koopmanschap MA \& Rutten F. Indirect costs in economic studies: confronting the confusion . PharmacoEconomics 1993;4(6): 446-54.

(18)* Luce BR \& Elixhauser A. Estimating costs in the economic evaluation of medical technologies. International Journal of Technology Assessment in Health Care 1990;6: $57-75$.

(18) Backhouse MW, Backhouse RJ \& Edey SA. Economic evaluation bibliography. $\underline{\text { Health }}$ Economics 1992;1: 1-236.

(20) Elixhauser A. Health care cost-benefit and cost-effectiveness analysis (CEA/CBA) from 1979-1990: a bibliography. Medical Care 1993;31: JS1-11, JS18-149.

(21)* Mugford M \& Mlika-Cabanne N. Evaluation of different policies of management of labour for primiparous women: first report from the economic evaluation. In: Kaminski M (ed) Evaluation of pre-, peri-, and post-natal care delivery systems. A European Concerted Action. Villejuif Cedex: INSERM, 1992. pp. 70-83. 
(22)* Glazener C. Investigation of postnatal experience and care in Grampian [PhD thesis]. Aberdeen: University of Aberdeen, 1999.

(23) Enkin M, Keirse MJNC \& Chalmers I. A guide to effective care in pregnancy and childbirth. Oxford: Oxford University Press, 1989.

(24) Petrou S, Coyle D \& Fraser WD on behalf of the PEOPLE (Pushing Early or Pushing Late with Epidural) Study Group. Cost effectiveness of a delayed pushing policy under epidural anaesthesia. American Journal of Obstetrics and Gynecology 2000;182(5): 1158-1164.

(25)* McNiven P, Hodnett E \& O’Brien-Pallas LL. Supporting women in labor: a work sampling study of the activities of labor and delivery nurses. Birth 1992;19: 3-8.

(26) Gagnon AJ \& Waghorn K. Supportive care by maternity nurses: a work sampling study in an intrapartum unit. Birth 1996;23(1): 1-6.

(27) Fuchs VR \& Perreault L. Expenditures for reproduction related health care. Journal of American Medical Association 1986;255(1): 76-81. 
(28) Gold RB, Kenney AM \& Singh S. Paying for maternity care in the United States. Family Planning Perspective 1987;19(5): 190-206.

(29) Zhang J, Bowes WA \& Fortney JA. Efficacy of external cephalic version: a review. Obstetrics and Gynecology 1993; 82(2): 306-12.

(30) Hundley V. The relative costs of intrapartum care in a midwife-managed delivery unit and a consultant-supervised labour ward [MSc Thesis]. Aberdeen: University of Aberdeen, 1994.

(31) MacKenzie IZ, Magill P \& Burns E. Randomised trial of one versus two doses of prostaglandin E2 for induction of labour: 2. Analysis of cost. British Journal of Obstetrics and Gynaecology 1997;104(9): 1068-72.

(32) Henderson J, Mugford M, Kavanagh S, Fraser W, Mlika-Cabanne N, Maillard et al. (1998). Professional issues. Economic evaluation of early amniotomy in low risk women. British Journal of Midwifery 1998;6(1): 28-32.

(33) Guasticchi G \& Signorelli C. [The costs of cesarean section compared to vaginal delivery: an economic analysis as related to an average-size hospital]. Ann Ig 1991; 3(5): 293-7.

(34) Riley ET, Cohen SE, Macario A, Desai JB \& Ratner EF. Spinal versus epidural 
anesthesia for cesarean section: a comparison of time efficiency, costs, charges, and complications. Anesthesia and Analgesia 1995;80(4): 709-12.

(35) Cohen SE, Subak LL, Brose WG \& Halpern J. Analgesia after cesarean delivery: patient evaluations and costs of five opioid techniques. Regional Anesthesia 1991;16(3): 141-9.

(36) Gerancher JC, Floyd H \& Eisenach J. Determination of an effective dose of intrathecal morphine for pain relief after cesarean delivery. Anesthesia and Analgesia 1999;88(2): 346-51.

(37)* Clark L, Mugford M \& Paterson C. How does the mode of delivery affect the cost of maternity care? British Journal of Obstetrics and Gynaecology 1991;98(6): 519-23.

(38) Scott A. A cost analysis of early discharge and domiciliary visits versus standard hospital care for low-risk obstetric clients. Australian Journal of Public Health 1994; 18(1): 96-100.

(39) Kramer RL, Gilson GJ, Morrison DS, Martin D, Gonzales JL, Qualls CR et al. A randomized trial of misoprostol and oxytocin for induction of labor: safety and efficacy. Obstetrics and Gynecology 1997;89(3): 387-91. 
(40) Chollet DJ, Newman JF \& Sumner AT. The cost of poor birth outcomes in employersponsored health plans. Medical Care 1996;34(12): 1219-34.

(41) Shorten A, Lewis DE \& Shorten B. Trial of labour versus elective repeat caesarean section: a cost-effectiveness analysis. Australian Health Review 1998;21(1): 8-28.

(42) Flanagan TA, Mulchahey KM, Korenbrot CC, Green JR \& Laros RK. Management of term breech presentation. American Journal of Obstetrics and Gynecology 1987;156(6): 1492-502.

(43) Traynor JD \& Peaceman AM. Maternal hospital charges associated with trial of labor versus elective repeat cesarean section. Birth 1998;25(2): 81-4.

(44) Gifford DS, Keeler E \& Kahn KL. Reductions in cost and cesarean rate by routine use of external cephalic version: a decision analysis. Obstetrics and Gynecology 1995;85(6): 930-6.

(45) Kilpatrick SJ \& Safford KL. Repeat external cephalic version. Is it worth the effort? Journal of Reproductive Medicine 1995;40(11): 775-8. 
(46) Davies L \& Drummond M. Management of labour: consumer choice and cost implications. Journal of Obstetrics and Gynaecology 1991;11: S28-S33.

(47) Robertson PA, Laros RK Jr \& Zhao RL. Neonatal and maternal outcome in low-pelvic and mid-pelvic operative deliveries. American Journal of Obstetrics and Gynecology 1990;162(6):1436-42.

(48) Astbury J, Brown S, Lumley J \& Small R. Birth events, birth experiences and social differences in postnatal depression. Australian Journal of Public Health 1994;18(2):176-84.

(49) Ryding EL, Wijma B \& Wijma K. Post-traumatic stress reactions after emergency caesarean section. Acta Obstetricia et Gynecologica Scandinavica 1997;76(9): 856-61.

(50) Hemminki E. Impact of caesarean section on future pregnancy - a review of cohort studies. Paediatric and Perinatal Epidemiology 1996;10(4):366-79.

(51) Johanson R \& Menon V. Soft versus rigid vacuum extractor cups for assisted vaginal delivery. (Cochrane Review). In: The Cochrane Library. Issue 2. Oxford: Update Software, 1999.

(52) MacKenzie IZ. Should women who elect to have caesarean sections pay for them? [letter]. British Medical Journal 1999;318(7190): 1070. 
Table 1: Examples of costs attributable to caesarean section and alternative modes of delivery

\section{Direct costs}

Hospital service costs

Medical and surgical supplies:

Delivery packs

Gowns

Gloves

Masks

Maternity pads

Inco pads

Sanitary towels

Support stockings

Syringes

Needles

Razors

Tape

Unoplast

Syntocinon

Syntometrin

Lignocaine

Vitamin K

Plastic cord clamp

Spencer wells forceps

Rotational forceps

Extraction cup

Urinary catheter

Obstetric cream

Swabbing solution

Betidine solution

Epidural

General anaesthesia

Diatherme sets

Equipment:

Mucus extractor

Blood gas machine

Ventouse machine

Resuscitaire

Direct patient support:

Drugs

Parental nutrition

Milk, feeds and catering

Medical gases

Imaging

Physiotherapy

Total pathology
Staff costs:

Medical staff

Nursing staff

Midwifery staff

Support staff

Support services:

Electricity

Coal/oil/gas

Water/sewerage

Local government taxes

Portering

Cleaning

Laundry

Hospital administration

Postage and telephone

Medical records

Ambulance services

Community service costs

Midwives

Day care services

Prescribed medications

General practitioners

Practice nurses

Physiotherapists

Counsellors

Psychologists

Psychiatrists

Social workers

Home visitors

Volunteers

Direct non-medical costs

Respite care

Hospital visiting costs

Additional child care costs

Additional help with

housework

Adaptations to home

Dietary requirements

Additional bedding

Additional clothing

Additional heating

requirements

\section{Indirect costs}

Changes in productivity

resulting from:

Changes in health status

Morbidity

Mortality

Income lost by family

members

Foregone leisure time

Time spent by patient seeking medical services

Time spent by family and

friends attending patients

(e.g. hospital visits)

\section{Intangible costs}

\section{Psychosocial costs}

Apprehension, anxiety, grief and loss of well-being associated with impending disfigurement, economic and physical dependence.

Social isolation

Family conflict

Valuations others put on patients' health and wellbeing

Pain

Changes in social functioning and activities of daily living 
Table 2: Length of labour (hours:mins) by mode of delivery, former North West Thames Region, 1995-97.

\begin{tabular}{|c|c|c|c|c|c|c|c|c|c|c|}
\hline \multirow[t]{2}{*}{ Category } & \multicolumn{2}{|c|}{ Spontaneous (70.1\%) } & \multicolumn{2}{|c|}{ Forceps (5.0\%) } & \multicolumn{2}{|c|}{ Ventouse (7.3\%) } & \multicolumn{2}{|c|}{ Elective CS (6.6\%)* } & \multicolumn{2}{|c|}{ Emergency CS (11.0\%) } \\
\hline & $\begin{array}{c}\text { Mean } \\
(95 \% \text { CI) }\end{array}$ & $\begin{array}{c}\text { Median } \\
\left(10^{\text {th }}-90^{\text {th }}\right. \\
\text { percentile })\end{array}$ & $\begin{array}{c}\text { Mean } \\
(95 \% \text { CI })\end{array}$ & $\begin{array}{c}\text { Median } \\
\left(10^{\text {th }}-90^{\text {th }}\right. \\
\text { percentile })\end{array}$ & $\begin{array}{c}\text { Mean } \\
(95 \% \text { CI })\end{array}$ & $\begin{array}{c}\text { Median } \\
\left(1^{\text {th }}-90^{\text {th }}\right. \\
\text { percentile })\end{array}$ & $\begin{array}{c}\text { Mean } \\
(95 \% \text { CI })\end{array}$ & $\begin{array}{c}\text { Median } \\
\left(10^{\text {th }}-90^{\text {th }}\right. \\
\text { percentile })\end{array}$ & $\begin{array}{c}\text { Mean } \\
(95 \% \text { CI })\end{array}$ & $\begin{array}{c}\text { Median } \\
\left(10^{\text {th }}-90^{\text {th }}\right. \\
\text { percentile })\end{array}$ \\
\hline $\begin{array}{l}\text { All deliveries } \\
(\mathrm{N}=111,321)\end{array}$ & $\begin{array}{c}6: 35 \\
(6: 33- \\
6: 37) \\
\end{array}$ & $\begin{array}{c}5.41 \\
(2.16- \\
12.16) \\
\end{array}$ & $\begin{array}{c}11: 19 \\
(11: 11- \\
11: 27) \\
\end{array}$ & $\begin{array}{l}11.07 \\
(4.55- \\
18.12) \\
\end{array}$ & $\begin{array}{c}10: 59 \\
(10: 52- \\
11: 05)\end{array}$ & $\begin{array}{l}10.42 \\
(4.58- \\
17.38) \\
\end{array}$ & $\begin{array}{c}0.11 \\
(0.09- \\
0.13) \\
\end{array}$ & $\begin{array}{c}0.00 \\
(0.00- \\
0.00)\end{array}$ & $\begin{array}{c}7: 30 \\
(7: 23- \\
7: 37) \\
\end{array}$ & $\begin{array}{c}6.42 \\
(0.00- \\
16.55) \\
\end{array}$ \\
\hline $\begin{array}{l}<37 \text { weeks } \\
(\mathrm{N}=7676)\end{array}$ & $\begin{array}{c}5: 52 \\
(5: 44- \\
6: 00) \\
\end{array}$ & $\begin{array}{c}4.59 \\
(1.48- \\
11.11) \\
\end{array}$ & $\begin{array}{c}8: 06 \\
(7: 31- \\
8: 40)\end{array}$ & $\begin{array}{c}7.25 \\
(3.09- \\
14.34) \\
\end{array}$ & $\begin{array}{c}9: 06 \\
(8: 31- \\
9: 42)\end{array}$ & $\begin{array}{c}8.30 \\
(3.19- \\
15.36) \\
\end{array}$ & $\begin{array}{c}0.27 \\
(0.16- \\
0.38) \\
\end{array}$ & $\begin{array}{c}0.00 \\
(0.00- \\
0.00) \\
\end{array}$ & $\begin{array}{c}2: 03 \\
(1: 52- \\
2: 14) \\
\end{array}$ & $\begin{array}{c}0.00 \\
(0.00- \\
7.23) \\
\end{array}$ \\
\hline $\begin{array}{l}\geq 37 \text { weeks } \\
(N=103,598)\end{array}$ & $\begin{array}{c}6: 37 \\
(6: 35- \\
6: 39) \\
\end{array}$ & $\begin{array}{c}5.43 \\
(2.17- \\
12.19) \\
\end{array}$ & $\begin{array}{c}11: 28 \\
(11: 19- \\
11: 36) \\
\end{array}$ & $\begin{array}{l}11.17 \\
(5.05- \\
18.15) \\
\end{array}$ & $\begin{array}{c}11: 02 \\
(10: 55- \\
11: 08) \\
\end{array}$ & $\begin{array}{l}10.45 \\
(5.00- \\
17.41) \\
\end{array}$ & $\begin{array}{c}0.10 \\
(0.08- \\
0.12) \\
\end{array}$ & $\begin{array}{c}0.00 \\
(0.00- \\
0.00)\end{array}$ & $\begin{array}{c}8: 40 \\
(8: 32- \\
8: 48)\end{array}$ & $\begin{array}{c}8.16 \\
(0.00- \\
17.34)\end{array}$ \\
\hline $\begin{array}{l}\text { Singletons } \\
(\mathrm{N}=108,195)\end{array}$ & $\begin{array}{c}6: 35 \\
(6: 33- \\
6: 37) \\
\end{array}$ & $\begin{array}{c}5.41 \\
(2.16- \\
12.16) \\
\end{array}$ & $\begin{array}{c}11: 21 \\
(11: 13- \\
11: 29) \\
\end{array}$ & $\begin{array}{l}11.10 \\
(4.55- \\
18.12) \\
\end{array}$ & $\begin{array}{c}11: 00 \\
(10: 54- \\
11: 07) \\
\end{array}$ & $\begin{array}{l}10.44 \\
(4.58- \\
17.39) \\
\end{array}$ & $\begin{array}{c}0.10 \\
(0.09- \\
0.12) \\
\end{array}$ & $\begin{array}{c}0.00 \\
(0.00- \\
0.00) \\
\end{array}$ & $\begin{array}{c}7: 36 \\
(7: 28- \\
7: 43)\end{array}$ & $\begin{array}{c}6.50 \\
(0.00- \\
16.58)\end{array}$ \\
\hline $\begin{array}{l}\text { Multiple births } \\
(\mathrm{N}=3126)\end{array}$ & $\begin{array}{c}6: 11 \\
(5: 51- \\
6: 31) \\
\end{array}$ & $\begin{array}{c}5.12 \\
(2.00- \\
11.34) \\
\end{array}$ & $\begin{array}{c}9: 39 \\
(8: 46- \\
10: 33)\end{array}$ & $\begin{array}{c}9.07 \\
(4.28- \\
16.15) \\
\end{array}$ & $\begin{array}{c}9: 45 \\
(9: 03- \\
10: 27)\end{array}$ & $\begin{array}{c}9.11 \\
(4.50- \\
16.55) \\
\end{array}$ & $\begin{array}{c}0.30 \\
(0.15- \\
0.45) \\
\end{array}$ & $\begin{array}{c}0.00 \\
(0.00- \\
0.00)\end{array}$ & $\begin{array}{c}5: 06 \\
(4: 32- \\
5: 40) \\
\end{array}$ & $\begin{array}{c}3.01 \\
(0.00- \\
14.19) \\
\end{array}$ \\
\hline $\begin{array}{l}\text { Primiparous } \\
(\mathrm{N}=48,585)\end{array}$ & $\begin{array}{c}8: 49 \\
(8: 46- \\
8: 53) \\
\end{array}$ & $\begin{array}{c}8.11 \\
(3.43- \\
14.56) \\
\end{array}$ & $\begin{array}{c}11: 47 \\
(11: 39- \\
11: 56)\end{array}$ & $\begin{array}{l}11.36 \\
(5.32- \\
18.31) \\
\end{array}$ & $\begin{array}{c}11: 32 \\
(11: 25- \\
11: 39)\end{array}$ & $\begin{array}{l}11.18 \\
(5.25- \\
18.13) \\
\end{array}$ & $\begin{array}{c}0.19 \\
(0.14- \\
0.24) \\
\end{array}$ & $\begin{array}{c}0.00 \\
(0.00- \\
0.00) \\
\end{array}$ & $\begin{array}{c}8: 38 \\
(8: 28- \\
8: 47) \\
\end{array}$ & $\begin{array}{c}8.20 \\
(0.00- \\
17.56) \\
\end{array}$ \\
\hline $\begin{array}{l}\text { Parous } \\
(\mathrm{N}=62,735)\end{array}$ & $\begin{array}{c}5: 20 \\
(5: 19- \\
5: 22)\end{array}$ & $\begin{array}{c}4.40 \\
(1.57- \\
9.37)\end{array}$ & $\begin{array}{c}8: 49 \\
(8: 31- \\
9: 07)\end{array}$ & $\begin{array}{c}8.22 \\
(3.21- \\
14.32)\end{array}$ & $\begin{array}{c}9: 01 \\
(8: 49- \\
9: 13)\end{array}$ & $\begin{array}{c}8.32 \\
(3.52- \\
14.42)\end{array}$ & $\begin{array}{c}0.08 \\
(0.06- \\
0.10)\end{array}$ & $\begin{array}{c}0.00 \\
(0.00- \\
0.00)\end{array}$ & $\begin{array}{c}5: 27 \\
(5: 16- \\
5: 37)\end{array}$ & $\begin{array}{c}4.09 \\
(0.00- \\
13.47)\end{array}$ \\
\hline $\begin{array}{l}\text { Year } 1995 \\
(\mathrm{~N}=36,895)\end{array}$ & $\begin{array}{c}6: 37 \\
(6: 34- \\
6: 40) \\
\end{array}$ & $\begin{array}{c}5.45 \\
(2.18- \\
12.15) \\
\end{array}$ & $\begin{array}{c}11: 22 \\
(11: 09- \\
11: 35)\end{array}$ & $\begin{array}{l}11.07 \\
(5.05- \\
18.10) \\
\end{array}$ & $\begin{array}{c}11: 00 \\
(10: 49- \\
11: 11)\end{array}$ & $\begin{array}{l}10.41 \\
(5.05- \\
17.40) \\
\end{array}$ & $\begin{array}{c}0.12 \\
(0.09- \\
0.16) \\
\end{array}$ & $\begin{array}{c}0.00 \\
(0.00- \\
0.00) \\
\end{array}$ & $\begin{array}{c}7: 38 \\
(7: 25- \\
7: 51) \\
\end{array}$ & $\begin{array}{c}6.49 \\
(0.00- \\
17.08) \\
\end{array}$ \\
\hline $\begin{array}{l}\text { Year 1996 } \\
(\mathrm{N}=37,400)\end{array}$ & $\begin{array}{c}6: 36 \\
(6: 33- \\
6: 39) \\
\end{array}$ & $\begin{array}{c}5.42 \\
(2.15- \\
12.16) \\
\end{array}$ & $\begin{array}{c}11: 16 \\
(11: 02- \\
11: 30)\end{array}$ & $\begin{array}{l}11.10 \\
(4.49- \\
18.04) \\
\end{array}$ & $\begin{array}{c}11: 06 \\
(10: 55- \\
11: 18) \\
\end{array}$ & $\begin{array}{l}10.45 \\
(5.03- \\
17.55) \\
\end{array}$ & $\begin{array}{c}0.12 \\
(0.08- \\
0.15) \\
\end{array}$ & $\begin{array}{c}0.00 \\
(0.00- \\
0.00) \\
\end{array}$ & $\begin{array}{c}7: 27 \\
(7: 14- \\
7: 39) \\
\end{array}$ & $\begin{array}{c}6.43 \\
(0.00- \\
16.54) \\
\end{array}$ \\
\hline $\begin{array}{l}\text { Year 1997 } \\
(\mathrm{N}=37,026)\end{array}$ & $\begin{array}{c}6: 32 \\
(6: 29- \\
6: 35) \\
\end{array}$ & $\begin{array}{c}5.38 \\
(2.15- \\
12.15) \\
\end{array}$ & $\begin{array}{c}11: 19 \\
(11: 05- \\
11: 34) \\
\end{array}$ & $\begin{array}{l}11.02 \\
(4.45- \\
18.19) \\
\end{array}$ & $\begin{array}{c}10: 50 \\
(10: 40- \\
11: 01)\end{array}$ & $\begin{array}{l}10.40 \\
(4.44- \\
17.21) \\
\end{array}$ & $\begin{array}{c}0.10 \\
(0.07- \\
0.13) \\
\end{array}$ & $\begin{array}{c}0.00 \\
(0.00- \\
0.00) \\
\end{array}$ & $\begin{array}{c}7: 26 \\
(7: 14- \\
7: 38) \\
\end{array}$ & $\begin{array}{c}6.34 \\
(0.00- \\
16.45) \\
\end{array}$ \\
\hline
\end{tabular}

Source: SMMIS

$11: 34)$

18.19)

11:01)

$17.21)$

$0.13)$

$0.00)$

16.45) 
Table 3: Medical and nursing staff present during caesarean section and alternative modes of delivery

\begin{tabular}{|c|c|c|c|c|c|c|c|c|}
\hline \multirow{2}{*}{$\begin{array}{l}\text { Category of staff / } \\
\text { mode of delivery }\end{array}$} & \multicolumn{6}{|c|}{ Mean number of staff } & \multirow[t]{2}{*}{ SD } & \multirow{2}{*}{$\begin{array}{c}\text { Number of } \\
\text { units } \\
\text { providing } \\
\text { data }\end{array}$} \\
\hline & Belgium & France & Greece & Italy & UK & All & & \\
\hline \multicolumn{9}{|c|}{ Midwifery and nursing staff } \\
\hline Vaginal delivery & 2.00 & 1.38 & 2.00 & 1.00 & 1.92 & 1.69 & 0.55 & 21 \\
\hline Caesarean section & 1.25 & 1.75 & 4.00 & 2.00 & 3.17 & 2.29 & 1.12 & 21 \\
\hline \multicolumn{9}{|c|}{ Additional junior medical staff } \\
\hline Vaginal delivery & 0.50 & 0.13 & 1.00 & 0.00 & 0.00 & 0.24 & 0.43 & 21 \\
\hline Forceps delivery & 1.13 & 0.50 & 2.00 & - & 0.42 & 0.75 & 0.68 & 20 \\
\hline Vaginal delivery & 0.75 & 0.25 & 0.00 & 1.00 & 0.00 & 0.29 & 0.45 & 21 \\
\hline Forceps delivery & 1.63 & 1.19 & 2.50 & - & 1.58 & 1.52 & 0.72 & 20 \\
\hline Vacuum extraction & 1.38 & 0.80 & 2.00 & - & 1.38 & 1.27 & 0.70 & 15 \\
\hline Caesarean section & 1.50 & 1.44 & 3.00 & 3.50 & 3.00 & 2.14 & 0.87 & 21 \\
\hline
\end{tabular}

Source: [21] 
Table 4: Duration of postnatal stay (days) by mode of delivery, former North West Thames Region, 1995-97.

\begin{tabular}{|c|c|c|c|c|c|c|c|c|c|c|}
\hline \multirow[t]{2}{*}{ Category } & \multicolumn{2}{|c|}{ Spontaneous (70.1\%) } & \multicolumn{2}{|c|}{ Forceps (5.0\%) } & \multicolumn{2}{|c|}{ Ventouse $(7.3 \%)$} & \multicolumn{2}{|c|}{ Elective CS (6.6\%) } & \multicolumn{2}{|c|}{ Emergency CS (11.0\%) } \\
\hline & $\begin{array}{c}\text { Mean } \\
(95 \% \text { CI) }\end{array}$ & $\begin{array}{l}\text { Median } \\
\left(10^{\text {th }}-90^{\text {th }}\right. \\
\text { percentile })\end{array}$ & $\begin{array}{c}\text { Mean } \\
(95 \% \text { CI })\end{array}$ & $\begin{array}{c}\text { Median } \\
\left(10^{\text {th }}-90^{\text {th }}\right. \\
\text { percentile })\end{array}$ & $\begin{array}{c}\text { Mean } \\
(95 \% \text { CI })\end{array}$ & $\begin{array}{c}\text { Median } \\
\left(10^{\text {th }}-90^{\text {th }}\right. \\
\text { percentile })\end{array}$ & $\begin{array}{c}\text { Mean } \\
(95 \% \text { CI })\end{array}$ & $\begin{array}{c}\text { Median } \\
\left(10^{\text {th }}-90^{\text {th }}\right. \\
\text { percentile })\end{array}$ & $\begin{array}{c}\text { Mean } \\
(95 \% \text { CI })\end{array}$ & $\begin{array}{l}\text { Median } \\
\left(10^{\text {th }}-90^{\text {th }}\right. \\
\text { percentile })\end{array}$ \\
\hline $\begin{array}{l}\text { All deliveries } \\
(\mathrm{N}=111,321)\end{array}$ & $\begin{array}{c}1.58 \\
(1.57- \\
1.60) \\
\end{array}$ & $\begin{array}{c}1.00 \\
(0.00- \\
3.00) \\
\end{array}$ & $\begin{array}{c}2.71 \\
(2.66- \\
2.77) \\
\end{array}$ & $\begin{array}{c}2.00 \\
(1.00- \\
5.00) \\
\end{array}$ & $\begin{array}{c}2.44 \\
(2.39- \\
2.48) \\
\end{array}$ & $\begin{array}{c}2.00 \\
(1.00- \\
4.00) \\
\end{array}$ & $\begin{array}{c}4.52 \\
(4.46- \\
4.57) \\
\end{array}$ & $\begin{array}{c}4.00 \\
(3.00- \\
6.00) \\
\end{array}$ & $\begin{array}{c}5.05 \\
(5.00- \\
5.11) \\
\end{array}$ & $\begin{array}{c}5.00 \\
(3.00- \\
7.00) \\
\end{array}$ \\
\hline $\begin{array}{l}<37 \text { weeks } \\
(\mathrm{N}=7676)\end{array}$ & $\begin{array}{c}3.61 \\
(3.49- \\
3.74)\end{array}$ & $\begin{array}{l}3.00 \\
(1.00- \\
8.00)\end{array}$ & $\begin{array}{c}5.03 \\
(4.44- \\
5.62)\end{array}$ & $\begin{array}{c}4.00 \\
(1.80- \\
9.00)\end{array}$ & $\begin{array}{c}5.25 \\
(4.81- \\
5.69)\end{array}$ & $\begin{array}{c}5.00 \\
(1.00- \\
9.00)\end{array}$ & $\begin{array}{c}6.62 \\
(6.26- \\
6.97)\end{array}$ & $\begin{array}{c}5.00 \\
(4.00- \\
11.00)\end{array}$ & $\begin{array}{c}6.89 \\
(6.68- \\
7.10)\end{array}$ & $\begin{array}{c}6.00 \\
(4.00- \\
11.00)\end{array}$ \\
\hline $\begin{array}{l}\geq 37 \text { weeks } \\
(N=103,598)\end{array}$ & $\begin{array}{c}1.49 \\
(1.48- \\
1.50)\end{array}$ & $\begin{array}{c}1.00 \\
(0.00- \\
3.00)\end{array}$ & $\begin{array}{c}2.61 \\
(2.56- \\
2.66) \\
\end{array}$ & $\begin{array}{c}2.00 \\
(1.00- \\
5.00)\end{array}$ & $\begin{array}{l}2.36 \\
(2.32- \\
2.40) \\
\end{array}$ & $\begin{array}{c}2.00 \\
(1.00- \\
4.00)\end{array}$ & $\begin{array}{c}4.36 \\
(4.31- \\
4.41) \\
\end{array}$ & $\begin{array}{c}4.00 \\
(3.00- \\
6.00) \\
\end{array}$ & $\begin{array}{c}4.66 \\
(4.62- \\
4.70) \\
\end{array}$ & $\begin{array}{c}4.00 \\
(3.00- \\
6.00) \\
\end{array}$ \\
\hline $\begin{array}{l}\text { Singletons } \\
(\mathrm{N}=108,195)\end{array}$ & $\begin{array}{c}1.56 \\
(1.55- \\
1.58)\end{array}$ & $\begin{array}{c}1.00 \\
(0.00- \\
3.00)\end{array}$ & $\begin{array}{c}2.66 \\
(2.60- \\
2.71)\end{array}$ & $\begin{array}{l}2.00 \\
(1.00- \\
5.00)\end{array}$ & $\begin{array}{l}2.38 \\
(2.34- \\
2.42)\end{array}$ & $\begin{array}{c}2.00 \\
(1.00- \\
4.00)\end{array}$ & $\begin{array}{c}4.44 \\
(4.38- \\
4.49)\end{array}$ & $\begin{array}{c}4.00 \\
(3.00- \\
6.00)\end{array}$ & $\begin{array}{c}4.99 \\
(4.94- \\
5.04)\end{array}$ & $\begin{array}{c}5.00 \\
(3.00- \\
7.00)\end{array}$ \\
\hline $\begin{array}{l}\text { Multiple births } \\
(\mathrm{N}=3126)\end{array}$ & $\begin{array}{c}4.40 \\
(4.10- \\
4.70)\end{array}$ & $\begin{array}{c}4.00 \\
(1.00- \\
8.00)\end{array}$ & $\begin{array}{c}5.77 \\
(4.98- \\
6.56)\end{array}$ & $\begin{array}{c}5.00 \\
(2.00- \\
10.60)\end{array}$ & $\begin{array}{c}5.45 \\
(4.93- \\
5.98)\end{array}$ & $\begin{array}{c}5.00 \\
(2.00- \\
9.00)\end{array}$ & $\begin{array}{c}6.09 \\
(5.72- \\
6.47)\end{array}$ & $\begin{array}{c}5.00 \\
(4.00- \\
10.00)\end{array}$ & $\begin{array}{c}6.67 \\
(6.32- \\
7.02)\end{array}$ & $\begin{array}{c}6.00 \\
(4.00- \\
10.00)\end{array}$ \\
\hline $\begin{array}{l}\text { Primiparous } \\
(\mathrm{N}=48,585)\end{array}$ & $\begin{array}{c}2.13 \\
(2.11- \\
2.16)\end{array}$ & $\begin{array}{c}2.00 \\
(1.00- \\
4.00)\end{array}$ & $\begin{array}{c}2.83 \\
(2.77- \\
2.88)\end{array}$ & $\begin{array}{c}2.00 \\
(1.00- \\
5.00)\end{array}$ & $\begin{array}{c}2.60 \\
(2.55- \\
2.64)\end{array}$ & $\begin{array}{c}2.00 \\
(1.00- \\
5.00)\end{array}$ & $\begin{array}{c}4.86 \\
(4.77- \\
4.96)\end{array}$ & $\begin{array}{c}4.00 \\
(3.00- \\
7.00)\end{array}$ & $\begin{array}{c}5.08 \\
(5.01- \\
5.15)\end{array}$ & $\begin{array}{c}5.00 \\
(3.00- \\
7.00)\end{array}$ \\
\hline $\begin{array}{l}\text { Parous } \\
(\mathrm{N}=62,735)\end{array}$ & $\begin{array}{c}1.28 \\
(1.26- \\
1.29)\end{array}$ & $\begin{array}{c}1.00 \\
(0.00- \\
2.00)\end{array}$ & $\begin{array}{c}2.10 \\
(1.94- \\
2.25)\end{array}$ & $\begin{array}{c}2.00 \\
(1.00- \\
4.00)\end{array}$ & $\begin{array}{c}1.87 \\
(1.78- \\
1.97)\end{array}$ & $\begin{array}{c}1.00 \\
(1.00- \\
4.00)\end{array}$ & $\begin{array}{c}4.37 \\
(4.30- \\
4.44)\end{array}$ & $\begin{array}{c}4.00 \\
(3.00- \\
6.00)\end{array}$ & $\begin{array}{c}5.00 \\
(4.91- \\
5.09)\end{array}$ & $\begin{array}{c}5.00 \\
(3.00- \\
7.00)\end{array}$ \\
\hline $\begin{array}{l}\text { Year } 1995 \\
(\mathrm{~N}=36,895)\end{array}$ & $\begin{array}{c}1.65 \\
(1.63- \\
1.67) \\
\end{array}$ & $\begin{array}{c}1.00 \\
(0.00- \\
3.00) \\
\end{array}$ & $\begin{array}{l}2.78 \\
(2.70- \\
2.86) \\
\end{array}$ & $\begin{array}{c}2.00 \\
(1.00- \\
5.00)\end{array}$ & $\begin{array}{l}2.57 \\
(2.49- \\
2.65) \\
\end{array}$ & $\begin{array}{c}2.00 \\
(1.00- \\
5.00) \\
\end{array}$ & $\begin{array}{c}4.70 \\
(4.61- \\
4.78) \\
\end{array}$ & $\begin{array}{c}4.00 \\
(3.00- \\
6.00)\end{array}$ & $\begin{array}{c}5.16 \\
(5.08- \\
5.25) \\
\end{array}$ & $\begin{array}{c}5.00 \\
(3.00- \\
7.00) \\
\end{array}$ \\
\hline $\begin{array}{l}\text { Year 1996 } \\
(\mathrm{N}=37,400)\end{array}$ & $\begin{array}{c}1.59 \\
(1.57- \\
1.62)\end{array}$ & $\begin{array}{c}1.00 \\
(0.00- \\
3.00)\end{array}$ & $\begin{array}{c}2.72 \\
(2.62- \\
2.82) \\
\end{array}$ & $\begin{array}{c}2.00 \\
(1.00- \\
5.00)\end{array}$ & $\begin{array}{c}2.47 \\
(2.39- \\
2.55) \\
\end{array}$ & $\begin{array}{c}2.00 \\
(1.00- \\
4.00)\end{array}$ & $\begin{array}{c}4.58 \\
(4.46- \\
4.71) \\
\end{array}$ & $\begin{array}{c}4.00 \\
(3.00- \\
6.00)\end{array}$ & $\begin{array}{c}5.12 \\
(5.01- \\
5.22)\end{array}$ & $\begin{array}{c}5.00 \\
(3.00- \\
7.00)\end{array}$ \\
\hline $\begin{array}{l}\text { Year } 1997 \\
(\mathrm{~N}=37,026)\end{array}$ & $\begin{array}{c}1.51 \\
(1.49- \\
1.53)\end{array}$ & $\begin{array}{c}1.00 \\
(0.00- \\
3.00)\end{array}$ & $\begin{array}{c}2.62 \\
(2.51- \\
2.73) \\
\end{array}$ & $\begin{array}{c}2.00 \\
(1.00- \\
5.00) \\
\end{array}$ & $\begin{array}{c}2.29 \\
(2.22- \\
2.36) \\
\end{array}$ & $\begin{array}{c}2.00 \\
(1.00- \\
4.00)\end{array}$ & $\begin{array}{c}4.30 \\
(4.22- \\
4.37) \\
\end{array}$ & $\begin{array}{c}4.00 \\
(3.00- \\
6.00) \\
\end{array}$ & $\begin{array}{c}4.90 \\
(4.81- \\
4.99) \\
\end{array}$ & $\begin{array}{c}4.00 \\
(3.00- \\
7.00)\end{array}$ \\
\hline
\end{tabular}

Source: SMMIS 
Table 5: Range of costs cited in published studies that were transparent and robust in their costing methodology and referent NHS costs

\begin{tabular}{lccc}
\hline & \multicolumn{2}{c}{ Range of costs cited in literature } & NHS reference costs \\
\cline { 2 - 3 } & $\begin{array}{c}\text { Excluding postnatal } \\
\text { stay }\end{array}$ & $\begin{array}{c}\text { Including postnatal } \\
\text { stay }\end{array}$ & Including postnatal stay* \\
\hline Spontaneous vaginal delivery & $£ 36-£ 852$ & $£ 605-£ 1065$ & $£ 500-£ 855$ \\
\hline Instrumental vaginal delivery & $£ 673-£ 931$ & $£ 233-£ 1886$ & $£ 886-£ 1362$ \\
\hline Caesarean section & & & $£ 1393-£ 2040$ \\
\hline
\end{tabular}

* Inter-quartile range of uncomplicated non-elective cases (NHS Executive 1999) 
Table 6: Utilisation of health and informal care services during the first two months postpartum, Grampian Region, $1990-91$.

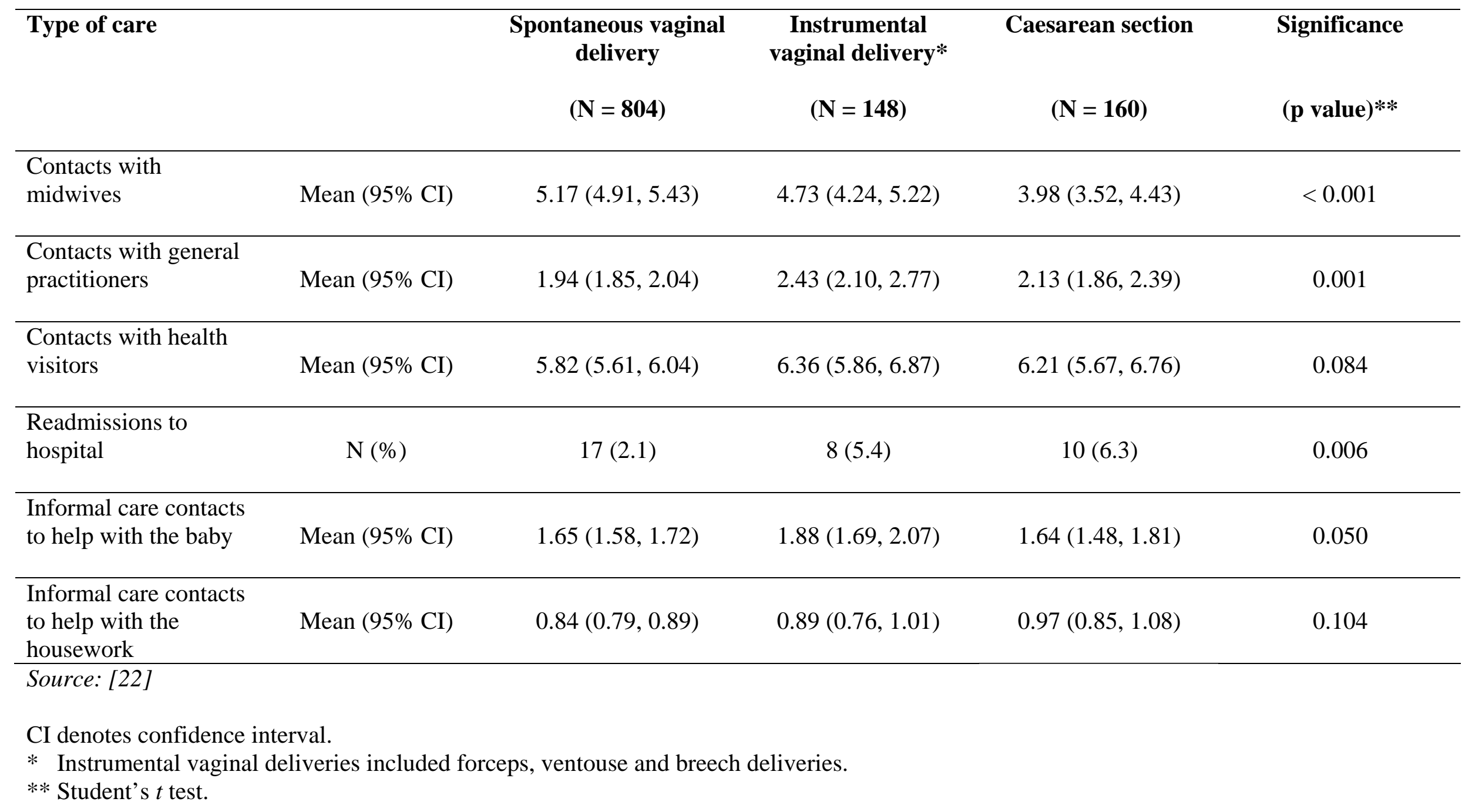


